\title{
Preface, Acknowledgments, and Apologies
}

\author{
Writing about Sex Magic; \\ or, How to Ruin Your Academic Career \\ and Your Sex Life All in One Go
}

Sex is a thing of the soul; most people think it but a mere matter of earthly form and physical structure. ... But its laws, offices, utilities and its deeper and diviner meanings are sealed books to all but about two in a million; yet they ought to have the attentive study of every rational human being, every aspirant to immortality beyond the grave.

paschal beVerly Randolph, Eulis! The History of Love (1874)

Sex is hardly ever just about sex.

SHIRLEY MACLAINE

When I first conceived the idea of writing a book on magia sexualis, or the tradition of sexual magic in the modern Western esotericism, I immediately encountered two very strong but completely opposite reactions. On one side, many friends and colleagues were naturally intrigued by the possibility of a book that could manage to take seriously a subject that is typically the province of New Age self-help manuals and pornographic Web sites on the Internet, while quoting Aleister Crowley, Emanuel Swedenborg, and Sting all in the same breath. On the other side, many strongly cautioned me against writing this book, sometimes sternly, sometimes emphatically, sometimes for personal reasons, sometimes for academic and professional reasons. After all, what better way to destroy one's scholarly reputation and look like a opportunistic hack than to write a book on sex magic that will very likely join the shelves of Barnes and Noble right beside Wicca for Lovers and The Multi-Orgasmic Man?

Meanwhile, much to my own (and my significant other's) dismay, I also discovered that a long and intensive investigation of the history of sexual magic is not in fact the best thing for one's personal or sexual relations. By the time I had finished writing this book, I had explored a staggering array of different uses, manipulations, and remarkably creative transformations of the sexual act, not to mention the transgression of nearly every imaginable 
sexual taboo and social boundary. Therefore, I apologize in advance to any readers who bought this book in the hope of finding the latest secrets of sexual ecstasy or a new method for achieving extended orgasm. The effect of this book upon the reader may well be, as it was for me, not so much erotic titillation as bewildering exhaustion.

Nonetheless, despite these apologetic opening remarks, I do think that both scholars of comparative religions and nonacademic readers should find something of interest in this book. As I will argue throughout, the history of sexual magic in modern esotericism is far from an obscure occult aberration or a superficial masking of sensual lust behind mystical gibberish. On the contrary, it opens some critical insights into the shifting attitudes toward sexuality, gender, religious authority, and social liberation over the last two hundred years. As Douglas Brooks has observed, there are many religious traditions that were at one time largely dismissed, ignored, and even denigrated by "serious" scholars of religion—such as Hindu and Buddhist Tantra, Jewish Kabbalah, and Christian mysticism - that are now considered to be on the cutting edge of current scholarship. ${ }^{1}$ In Shirley MacLaine's words, sex is hardly ever just about sex. On the contrary, it lies at the center of a series of much larger social, political, economic, moral, and religious issues that have become increasingly volatile in our own increasingly sexobsessed late capitalist consumer culture. As Jeffrey Weeks observes, "Sexuality today is, perhaps to an unprecedented degree, a contested zone. It is more than a source of intense pleasure or acute anxiety; it has become a moral and political battlefield. Behind the contesting forces ... lie contrary beliefs, languages, about the nature of sex; sex as pleasure, sex as sacrament, sex as a source of fear and loathing." ${ }^{2}$ And sexual magic, I will suggest, is about far more than the occult fantasy of manipulating or optimizing orgasm. Indeed, it brings into striking relief many of these social, moral, and political tensions, offering some surprising new perspectives of our own cultural history, not to mention the tense, often conflicting relationship between sexuality and spirituality in the modern era.

Perhaps most importantly, the literature on sexual magic forces us to reflect self-consciously and critically on our obsessions with sex and liberation in late capitalist consumer society at the turn of the millennium. As Michel Foucault has aptly observed, "It may well be that we talk about sex more than anything else. ... We convince ourselves that we have never said enough on the subject. ... It is possible that where sex is concerned, the most long-winded, the most impatient of societies is our own." ${ }^{\prime 3}$ In other words, the seemingly "magical" and "liberating" power of sex is by no means some quaint, archaic vestige of our premodern past, but something that contin- 
ues to fascinate, obsess, and tantalize us to this day. Indeed, one of the bestselling but intensely controversial novels of recent memory is Dan Brown's The DaVinci Code, which suggests that a secret tradition of Gnostic sexual rituals and veneration of the female body lies hidden beneath the official history narrated by the Catholic Church. The fact that even a fictional narrative of this sort should generate such outrage and debate is telling evidence that these are questions that still haunt us to this day. ${ }^{4}$

A brief note on the title of this book: it is taken from a French translation of the writings of Paschal Beverly Randolph (1825-75), arguably the single most important figure in the rise of modern sexual magic. First published in 1931 by a Russian émigré named Maria de Naglowska, who probably also added some inventions of her own, Magia Sexualis would become one of the most influential works on the subject and continues to be republished and widely read to this day. ${ }^{5} \mathrm{My}$ own book might be seen as a critical, historical counterpart to Randolph's text. That is to say, rather than offering a new technique for achieving optimal orgasm or sexually enhanced magical power, this book examines the historical context and sociopolitical implications of sexual magic as it has emerged over the last two hundred years.

There are a great many friends, colleagues, and editors who deserve thanks here: first, the various people who helped me conceive and refine this project, including Wendy Doniger, David Frankfurter, Wouter Hanegraaff, Jeffrey Kripal, Bruce Lincoln, Reed Malcolm, Marco Pasi, Arthur Versluis, Steve Wasserstrom, and Catherine Wessinger; second, those who will no doubt be perplexed or offended by this book, my mother and siblings; third, my truly magical, even if now largely asexual, canine companions, Shakti and Dorje; finally and most importantly, my own "Scarlet Woman," Nancy. 
